\title{
Communication in Social Media as a Reflection of the Noble Values of a Nation
}

\author{
Diah Ajeng Purwani
}

\begin{abstract}
The increase in the use of social media in our society certainly bring changes in the way and acts of communication whether the use of Facebook, Friendster, blogs, Instagram and Twitter. Digital media can be used as a vehicle to create the word of mouth. This research intends to see the cultural change of new communication between people. The social media has the ability to garner opinions that may develop in various forms, from social even to political interests. This medium moderates the personal problems into public discourse. A new era in the virtual world that is considered by many people to have negative side can also be viewed from the opposite side.
\end{abstract}

Index Terms-Communication 2.0, social media, noble values, cultural change.

\section{INTRODUCTION}

In 2012 the figure of Afriani Susanti previously is nobody but then she becomes a famous figure in Indonesia. Her case of deadly collision in Gambir Jakarta killing several people at once because of her drunken state has made the social networking in Indonesia horrendous (see Fig. 1-Fig. 3).

One of the news emerging in the Internet, sidominews in 2012 [1] is:

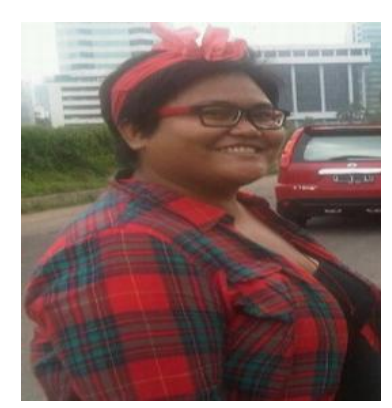

Fig.1. Afriani Susanti.

Afriani Susanti: 29-year-old girl whose name is never subsided in various media in the past two weeks. The sequence of news talking about her deadly racing action in Gambir continues to be publicized endlessly. The public in this country got shocked. They did not instantly believe it. How can a fat girl with her three friends in Daihatsu Xenia car kill nine people within a very short time. Moreover, Afriani Susanti herself was amazed. With an innocent face she got out of the car and simply said, "My brake is not

Manuscript received August 30, 2014; revised November 25, 2014.

Diah Ajeng Purwani is with the Department of Communication, Faculty of Social Science and the Humanities, Sunan Kalijaga State Islamic University, Yogyakarta, Indonesia (e-mail: ajeng_purwani@yahoo.com). working, Sir"1 .

It does not need to wait for a long time for this case to stick out in various media in Indonesia. Printed, electronic, and digital (online) media talked about it enthusiastically, including in the social media. In the media that has evolved into the social one, Afriani Susanti became a central figure of public insults and invective. But the rice has become the porridge. This case has widely spread. And Afriani Susanti has to reap the harvest after sowing the seed. Today the development of Afriani Susanti's case has come to the final round. It is said that the police are trying to sue the case of such an accident with murder. The effect is, Afriani Susanti will be under sentence of at least 15 years. Is it worth?

In fact, various negative reactions in the form of oblique comments are directly addressed to her Twitter account @ siNengApril. Not a few of them who felt pity on her and finally issued more polite statements. Due to the many negative reactions, her Twitter account was closed. People that formerly were not familiar with this figure then vie to access the info via the virtual world. Spreading the news are also accomplished via HP and BBM (Blackberry Messenger). The people feel connected to this figure and her family, as if they knew hers they have the right to comment.

The other news is death of Virginia Anggraeni, wife of pedangdut Saipul Jamil, because traffic accident in Toll Cipularang Km 96 Jakarta at the end of 2011. This news buzzes adorn a variety of social media. As an artist who has always highlighted, the news of the death of his wife syaiful jamil received response from among celebrities in Indonesia. They also delivered a speech saying condolence through social networking sites such as Twitter.

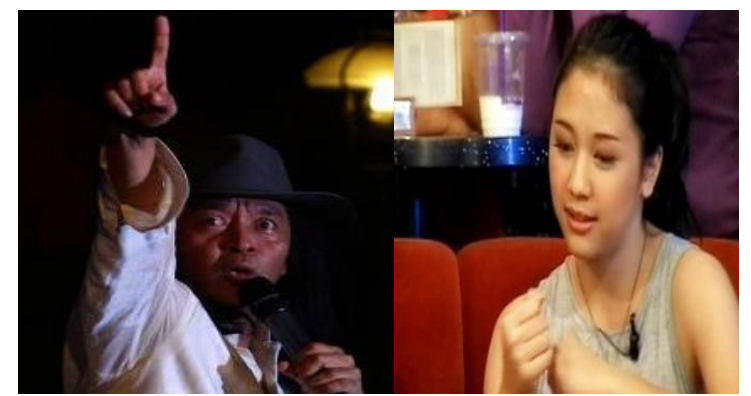

Fig. 2. Sujiwo Tejo VS Sherina.

One who delivered a speech of grief is singer Sherina Munaf. However the speech of grief the celebrities were then criticized by artists Sujiwo Tejo. He criticized the speech became one of the celebrities mourn it as the wrong greeting through his account twitter, @sudjiwotedjo. The word Sujiwo Tejo criticizing the speech ' to mourn ' harsh criticism

\footnotetext{
${ }^{1}$ Original text in Indonesian language
} 
of then got the tweets, including Sherina Munaf [2].

News of the death the wife Syaiful Jamil elicited various reactions. Positive and negative comments alternates adorn the various social networks in the country. One of them is the intense news coverage of the Fashingnet.com. News release via online case nearly every moment with the titles are "controversial". Fashingnet.com this site is ultimately delivered the apology over his announcement because of the various "complain" from various parties. This site also promised to be more careful in making meaning headline news.

\section{Social Media}

One of the interesting things from the social media is that people who do not know each other can get acquainted, be friends, best friends, and boyfriend or girlfriend, too. On the other hand, even without ever meeting face-to-face people can be "enemies" to each other, which is originated from insinuating to each other or not appreciating each other's opinion on the social media. The number of interactions in the social media is driven by technological advances recently. The development of social media is also motivated by everyone's desire to have his/her own media (blogs, Facebook, Twitter).

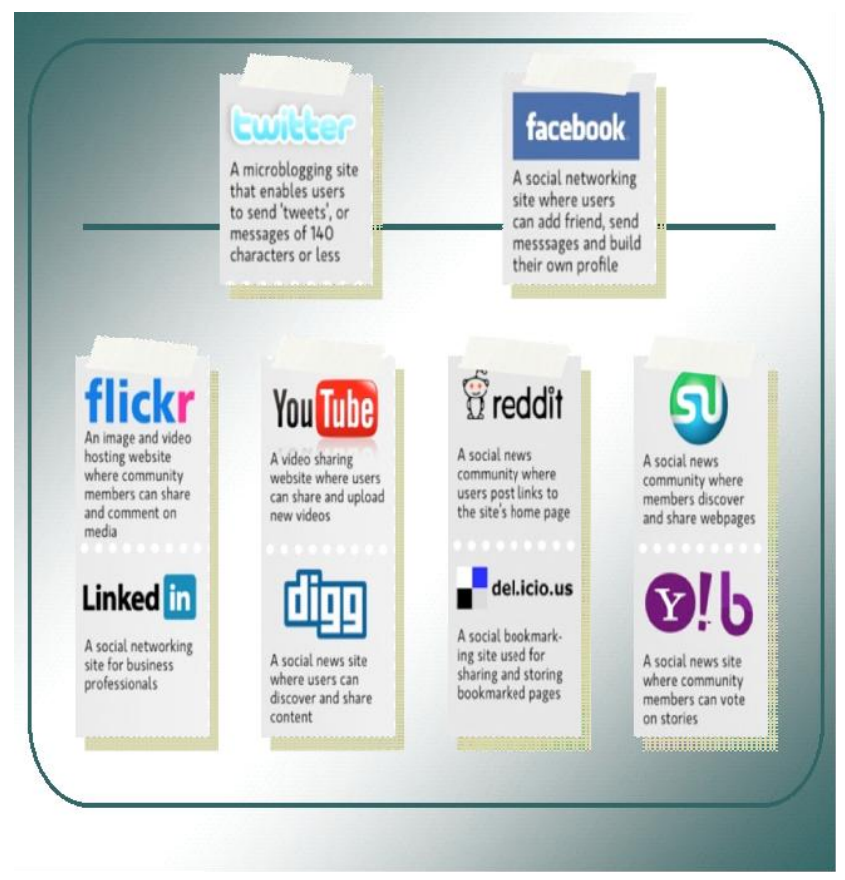

Fig. 3. Social media sample.

Social media users can do anything on their own even without having an employee. This is different from traditional media like newspapers that needs a lot of capital and labors. Social users can freely edit, add, and modify either writings, images, videos, graphics and other various things, especially related to the content. We can write whatever we want or even we are free to comment on anything other people write and present. This means that two-way communication has been established. By using the social media, all the things that are taboo can be done.

In a turgid way Kompas Indonesia daily newspaper [3] revealed that every one of a dozen people on the planet of
Earth has a Facebook account. Social networking is successfully connecting more than half a billion people and mapping their social relations. In a world of advanced technology and information, we are entering the hyper communications in which the media enables a communication not between a handful of people and the masses as it occurs on the radio, newspapers and television, but between one communicator and one communicant and also between the mass communicator and the mass communicant. Along with the development of human civilization, a new, more complex media is created to help people to cope with the challenges of communication that exist in each era. Following this, the new media also helps to change the way humans interact with each other. If previously the interaction among people is limited to the space and certain time, the technology media that exists today has been able to penetrate these restrictions.

This development makes the communication flow change. The news released via online appears almost all the time with titles that draw attention. Negative and positive comments successively adorn the various social networks in the country. Even many of them "aggravate" this condition with various languages that tend to exaggerate.

Such a thing is very common in the era of communication 2.0 in which all people can directly give various responses both positive and negative openly. The writer observes that the development occurs because of the social media. In Indonesia the artists' dispute like Sherina and Sujiwo Tejo when Saiful Jamil's wife died some time ago is just one example of the various kinds of interactions that occur in the social media in Indonesia.

Throughout the history, Baron said in his book entitled 'Advertising Media Planning' [4] the forms of mass media are determined and limited by technological developments. Technology restricts any form into a content type: printed words, sounds, images, and moving images that were originally black and white. Each is limited to one-way communication. Now, words, images, moving images, and interactivity have gathered on televisions; personal computers and mobile phones can be taken anywhere. The function of mobile phone as a means of communication has begun to shift, from just a tool for calling and sending SMS becomes a tool for chatting and updating status on Facebook and Twitter. A survey conducted by Nielsen [5], explained that the segments driving the increase of mobile phone penetration (to bet here fold in the last five years) in Indonesia today are the lower middle class and the young people. Chatting for young people is a better solution because it can give two-way communication satisfaction with various features including emoticons and conference. The nature of the content also has changed. Besides the materials are professionally produced, the content produced by YouTube users, social networking, blogs, Wikipedia, Twitter, and others can be read, heard and seen any time through various forms of the emerging new media. The internet gives the users the ability to search and retrieve information in seconds.

The growth in the use and popularity of social networking in Indonesia recently is very astonishing. Means of communication in social networking has grown rapidly such 
as Facebook, MySpace, Friendster, Plurk and Twitter. Interactive MIX magazine [6] revealed that according to the Expert Staff of Communication and Mass Media, the Ministry of Communications and Information Technology, the number of Facebook users in Indonesia today is at the second rank in the world, while the number of Twitter users in Indonesia is the largest one in Asia. So no wonder if many of them are utilizing the social media as a new contact point to interact and communicate with their target audiences. In the past, when Friendster was at its glorious time, social problems rarely emerged. But after Facebook has come, various problems emerge, ranging from hostility to divorce. One thing is clear, that the influence of Facebook is tremendous. Moral supports can be mobilized on Facebook. A lot of people now are already technologically literate.

The social media invites anyone interested in participating by giving contribution and feedback openly, giving comments and sharing information into the fast and infinite time. This communication model then creates the community quickly because of the same interests in something. By the help of social media technology, the type of communication WOM (word of mouth) is regarded as the most effective model of communication that should not be done face-to-face anymore. Facebook, Twitter and other social media are the tools that can be used to communicate with faster and wider spreading scope. Information in social media serves to influence each other. There is an increase in the use of social media in our society, whether the use of Facebook, Friendster, blog and Twitter that bring changes in the way and acts of communication, as well as bringing influence on cultural change in their lives. Now, almost all of them get into the digital realm via e-papers, websites and so on. So inevitably, the industry perpetrators must also change to follow the existing trend.

In the mid of the phenomenal use of social media, the presence of Kaskus online community is also a separate phenomenon. It is the first and largest online community in Indonesia which members now reach nearly 3 million accounts with the amount of access to 53 million per month. Kaskus is also phenomenal because its features are able to cover the needs of the members. The level of innovation is relatively substantial because it focuses on product innovation by trying to be the first to offer a product with specific features in its category.

\section{Cultural Change}

The increase in the use of social media in our society certainly bring changes in the way and acts of communication whether the use of Facebook, Friendster, blogs and Twitter. This will also bring influence on cultural change in their lives. The information product that at the beginning is elite (the information usually comes from a few people and is distributed to many people), is now moving from many people to much more people (the masses) [7]. The limitation of distance becomes very thin because everyone can produce and distribute information to multiple parties without boundaries. The social media is now being used for issues and various social discourses.

It is already common in the era of communication 2.0 where everyone can instantly provide a variety of responses either positive or negative. Internet technology has penetrated into people's daily lives and made communication much easier and less expensive. In the case of "dispute" sherina and sujiwo tejo, there are various parties outside those who also provide the response directly. As we do this we can see that beneath the general sense of change we need to talk about a range of different kinds of change. One of them is fashingnet.com that his vigorous preaching it and ended up writing the statement apologize publicly. There are still many other comments which also sometimes inappropriate without apology. The authors observed that the growth occurred due to social media. Sujiwo Tejo and sherina feud is just one example of the wide variety of interactions that occur in social media.

The case of Sherina vs. Sujiwo Tejo at the end of 2011 and Afriliani in early 2012 in Indonesia is one example of how a rumor or gossip even defamation can quickly be spread widely within communication 2.0 in virtual world. Mutual negative comment (if you do not want to say blasphemous) is already something common. Is the moral of this national ready bad so that what is written in vulgar way in the social networking seems to be common? Clarification as performed by fashingnet.com is rarely done. Even if it is done, the news has widely spread and various kinds of comments come, that if the comments are noted, those are so far from the values of courtesy that were taught by our ancestors. Today many people get involved in the internet. They interact with each other socially, on the basis of mutual trust and communal. This phenomenon makes the blast of interactivity so powerful. We would quickly find ourselves encountering this situation by the social media.

In the two cases above and many other cases, the writer could see a lot of moral values that, without our realizing, have actually decorated the interactions that occur in the social media. When the noble values have already been embedded in ourselves, then we would be cautious in commenting on someone. In Javanese tradition, there is the element of "pakewuh" when we will comment openly on the tragedy experienced by someone. The criticisms and suggestions being delivered will be more polite and constructive instead of blaspheming without solutions. There is an "unggah-ungguh" in expressing something. Things like that are instilled by the parents in the past that later are less applied by the young generation. The development of technology is only able to be followed by a very few of the old generation. Young people, who are the perpetrators of social media, are very lively in writing words in Facebook, Twitter, blogs, and various other social networks. Thus, it is not weird when finally it becomes easier for the current generation to imitate various things that exist in social media either positive or negative.

\section{FINAL THOUGHTS}

The social media has the ability to garner opinions that may develop in various forms, from social even to political interests. This medium moderates the personal problems into public discourse. A new era in the virtual world that is considered by many people to have negative side can also be 
viewed from the opposite side. Various facilities being offered can be used to introduce the noble values of Indonesia that have been considered by some people to fade. When the era is changing, the learning methods must also change to adjust the changing times. Various opportunities that arise due to the sophistication of technology could be used to "re-introduce" various noble values of a nation. Philosophy of Javanese culture and culture of courtesy and noble values of previous generations could be echoed through the communication that occurs in the social media. Besides the good communication, another thing that can be done is by widely spreading the information about the examples of noble values to the people especially the young generation. One way to do this is by opening the media about anything needed to know about Indonesian nation starting from the history of the nation, the nation noble values contained in the grains of Pancasila, and many others using the Internet sites. Various business organizations in Indonesia are already doing this to develop the values. Thus, publicity is done under the control of the organization. So the learning about various courtesy ethics from the past can take part in the era of web 2.0.

Of course, the presentation of information should be attractively packaged. Digital media can be used as a vehicle to create the word of mouth, so the use of social media needs to be improved to instill various good things one of which is noble values contained in the grains of Pancasila to the young generation. It could be said here that it is a brand that can be widely introduced. When a brand is not doing interaction, it is synonymous with a human without a soul, a man who lost his spirit. So it simply must create an interaction between the noble values of this nation, one of which is contained in the grains of Pancasila, and the norms of society. Javanese culture and the culture of other regions in Indonesia that are kind, polite, tepo seliro, and many other scan be used as a way to communicate in social networks or virtual media. With this kind of meaning, it needs an integration of all aspects of communication to echo the noble values again.
Integration is a consistency towards the message of the campaign of noble values of the Indonesian nation globally.

Be aware that the use of Web 2.0 as a medium for the cultivation of the noble values of the nation is just a particle in the grand scheme of a communications campaign. When all can be integrated then among the messages of noble values of this nation, the media and the customer focus will produce a great understanding, especially for the young generation. Indeed, the social media is not just about the media, also not just about web 2.0. The social media is all about our social world that grows to a level never seen before in the human history.

\section{REFERENCES}

[1] I. Aziz. (Januari 2012). Afriani Deadly Racing Action. [Online] Available: http://www.sidominews.htm.

[2] Zonamaya. (Oktober 2011). Tanggapan Sherina. [Online]. Available: http://terorberita.blogspot.com/2011/09/tanggapan - sherina -tentangtweet-sujiwo.html

[3] Kompas Indonesia, Daily Newspaper, Kompas Indonesia, 2012.

[4] B. Roger and Jack Z Sissors, Advertising Media Planning, The McGraw-Hill Companies, 2010, ch. 2

[5] Lis., Mix Magazine, PT. Swa Media International, February 2012.

[6] Lis., Mix Magazine, PT. Swa Media International., August 2013.

[7] A. Liliweri, Komunikasi Serba Ada Serba Makna, Jakarta. Prenada Media Grup, 1ed., May 2011, ch. 6, pp. 124-135.

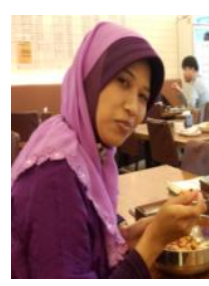

Diah Ajeng Purwani is a student program doctor in Gadjah Mada University, Indonesia. She is majored in development communication. Her has been published book: Rahasia hati, Kisah Indah penuh Keteladanan, Rahasia Ikhlas, etc. She works as a lecturer in Communication Department at Faculty of Socia Science and the Humanities, Sunan Kalijaga State Islamic University Yogyakarta, Indonesia.

Diah Ajeng Purwani, S. Sos, M. Si, Trainer in CTSD (Center for Teaching Staff Development), works as an expert in public relations, a researcher, a writer, frequently giving various trainings in branding, public relations and integrated marketing communication. 